\title{
PRELIMINARY DATA ON BRAZILIAN MONOFLORAL HONEY FROM THE NORTHEAST REGION USING FT-IR ATR SPECTROSCOPIC, PALYNOLOGICAL, AND COLOR ANALYSIS
}

\author{
Ligia Bicudo de Almeida-Muradian ${ }^{\mathrm{a}, *}$, Renato J. Sousa ${ }^{a}$, Ortrud Monika Barth ${ }^{\mathrm{b}}$ and Peter Gallmann \\ aDepartamento de Alimentos e Nutrição Experimental, Faculdade de Ciências Farmacêuticas, Universidade de São Paulo, Av. Prof. \\ Lineu Prestes 580, bloco 14, 05508-900 São Paulo - SP, Brasil \\ 'Instituto Oswaldo Cruz, FIOCRUZ, Avenida Brasil 4365, 21040-900 Rio de Janeiro - RJ, Brasil \\ ${ }^{\mathrm{c} S}$ Swiss Bee Research Centre/Agroscope Liebefeld-Posieux, Schwarzenburgstrasse 161, CH-14 3003 Bern, Switzerland
}

Recebido em 07/06/2013; aceito em 24/11/2013; publicado na web em 26/02/2014

\begin{abstract}
Fourier transform infrared attenuated total reflectance (FT-IR ATR) spectroscopy was used to determine 14 different measurands in northeast Brazilian honey samples. Nine different honey samples (six monofloral and three polyfloral) from 2009 obtained from the company CEARAPI underwent FT-IR ATR, palynological, color, and sensorial analysis to obtain preliminary results for these types of honey. The results showed that there are five monofloral, three bifloral, and one extrafloral honey, and also that mid-infrared spectrometry can be used as a screening method for the routine analysis of Brazilian honey, with the advantages of being rapid, nondestructive, and accurate.
\end{abstract}

Keywords: honey; pollen analysis; FT-IR ATR.

\section{INTRODUCTION}

Infrared (IR) Spectroscopy deals with the infrared part of the electromagnetic spectrum. It measures the absorption of different IR frequencies by a sample positioned in the path of an IR beam. Currently, infrared spectroscopy is one of the most common spectroscopic techniques used in the food industry. With the rapid development of infrared spectroscopic instrumentation software and hardware, the application of this technique has expanded into many areas of food research. It has become a powerful, fast, and nondestructive tool for food quality analysis and control. Fourier Transform (FT) Spectroscopy is an instrumental technique in which spectra are acquired based on measurements of electromagnetic radiation using time domain or space domain and a mathematical method (F T) is applied to convert the raw data to frequency domain. The main application of FT Spectroscopy is the acquisition of absorption spectra. ${ }^{1}$ IR is based on the absorption of electromagnetic radiation at wavelengths in the range between 800 and $2500 \mathrm{~nm}$. This technique has many advantages such as being rapid and nondestructive, and allows the determination of multiple measurands in a single step. ${ }^{2}$

Quantitative Infrared Spectroscopy is generally based on calibrations by partial least squares (PLS) regression between the spectra and the results obtained by physicochemical reference methods. Building the statistical model is relatively time consuming, and is only profitable if a large number of samples can be analyzed. ${ }^{2}$ In this study, a previously published calibration was used, ${ }^{3}$ which had been successfully used for predicting the physicochemical parameters in the quality control of stingless bee Brazilian honey. ${ }^{4}$

Infrared Spectroscopy of different monofloral honey samples and subsequent statistical analysis using principal component analysis (PCA) and linear discriminant analysis (LDA) showed that successful classification of the botanical origin of honey is possible. MIR (mid-infrared) spectroscopy has been successfully used for classification of monofloral European honey. ${ }^{2,5,6}$

Concerning honey, beyond quantitative analysis of different measurands, there is a practical need for measuring botanical

*e-mail: ligiabi@usp.br authenticity. Fourier transform infrared attenuated total reflectance (FT-IR ATR) spectroscopic technique was investigated for its feasibility for the identification of monofloral honey samples. ${ }^{7,8}$ The state of the art is that preliminary screening of honey types can be achieved by FT-IR techniques, but classic analysis such as melissopalynology and chemometrical as well as sensorial methods are required in the beginning to confirm the identification. ${ }^{9}$ Bogdanov et $a l$. reviewed the physicochemical methods for the characterization of European monofloral honey, but there is a need to characterize Brazilian honey as well. ${ }^{2}$

Color is the physical property most immediately perceived by consumers. In Europe, the price of honey depends on the honey color; generally the lightest ones are the costliest. Therefore, color is a useful and important parameter for classifying monofloral honey. ${ }^{2}$ The most commonly used method is based on optical comparison, using simple color grading, after Pfund.,10

Hydroxymethylfurfural (HMF) is not a criterion for the botanical classification of honey, but is a determining storage-dependent parameter. Fresh honey does not contain HMF, and this parameter is always used when the honey is exported. The Brazilian regulations establish a limit of $60 \mathrm{mg}$ of $\mathrm{HMF} / \mathrm{kg} .{ }^{11}$

Sensorial analysis is the examination of a product through the evaluation of the attributes perceptible by the five sense organs (organoleptic attributes): color, odor, taste, touch, texture, and noise. The technique is simple, and extensive work has been performed by members of the International Honey Commission to present the state of the art for sensory analysis applied to honey. ${ }^{12}$ Sensory evaluation enables us to distinguish the botanical origin of honey (previously standardized) and also to identify certain defects such as fermentation, off-odors, and flavors. ${ }^{12}$

Identification of pollen grains occurring inside honey is a useful tool to obtain information about its botanical origin. Avoiding the acetolysis procedure during sample preparation, other structural elements occurring in the honey sediment help to identify a monofloral, bifloral, heterofloral, and extrafloral source and adulterations as well as the hygienic conditions of the product. ${ }^{13,14}$ Pollen analysis of honey is always the basis of knowledge for subsequent physicochemical and sensorial analyses. ${ }^{15,16}$ 
The aim of this study was to characterize Brazilian monofloral honey from the northeast region through FT-IR ATR spectroscopic, HMF, color, palynological, and sensorial analysis.

\section{MATERIAL AND METHODS}

\section{Honey samples}

Nine samples of Brazilian organic honey were obtained from the CEARAPI-Apicultura e Produtos Orgânicos Ltda. Company, collected in the northeast of Brazil (Ceará state) during 2009. Six honey samples were stated to be monofloral by the beekeepers, with the common names of anjico, cipó-uva, mangue, marmeleiro, moleque duro, and vassourinha. (The respective scientific names are Mimosaceae: Anadenanthera colubrina, Sapindaceae: Paullinia carpopodea, Rhizophoraceae: Rhizophora mangle, Euphorbiaceae: Croton urundeuva, Boraginaceae: Cordia leucocephala, and Rubiaceae: Borreria verticillata.) Three honey samples were stated to be polyfloral (Polyfloral Hinterlands, Polyfloral Pre Amazon, and Polyflora)

\section{Fourier Transform Infrared Spectroscopy using the Attenuated Total Reflection - (FT-IR ATR) technique}

Infrared spectra were collected by direct measurement with Bruker Tensor 27 equipment using the same measuring conditions ${ }^{6}$ as previously described. ${ }^{3,4}$ The conditions of the analysis are listed below.

Equipment: A Tensor 27 Sample Compartment RT-DLaTGS (Bruker Optik GmbH, Germany) equipped with a MKII Golden Gate single-reflection ATR accessory (Specac Inc., Woodstock, GA) was used. The measuring cell consisted of a diamond $2.8 \mathrm{~mm}$ in diameter with a refractive index of 2.4 at $1,000 \mathrm{~cm}^{-1}$. The depth of penetration of the infrared radiation was $2.0 \mu \mathrm{m}$ at $1000 \mathrm{~cm}^{-1}$ for a sample with a refractive index of 1.5 (approximately the refractive index of honey). The spectrometer was equipped with a DigiTechTM 163 DLATGS detector, which covers a spectral range from $12,000 \mathrm{~cm}^{-1}$ to $370 \mathrm{~cm}^{-1}$ and operates at room temperature. The software used was Opus 6.5 (Bruker Optik GmbH, Germany).

Honey samples were liquefied in an oven at $55^{\circ} \mathrm{C}$ for $8 \mathrm{~h}$ and allowed to cool to room temperature before analysis. After a drop of the sample was placed on the surface of the diamond, it was left to equilibrate thermally for $4 \mathrm{~min}$. One hundred scans were recorded for each spectrum in the wavenumber range between $4,000 \mathrm{~cm}^{-1}$ and $550 \mathrm{~cm}^{-1}$ with a spectral resolution of $4 \mathrm{~cm}^{-1}$. Single beam spectra of all samples were recorded and ratioed against the background spectrum of the clean diamond surface (room temperature air) in order to present the spectra in absorbance. Two spectra were recorded at room temperature using different aliquots of each sample. After each measurement, the diamond was thoroughly washed with Milli-Q water and dried with a soft tissue.

\section{Chemometric modeling of the quantification, calibration, and validation}

The PLS calibration was performed for each measurand, using the software Opus 6.5 module Quant, and based on the model described by Ruoff et $a l .^{6}$ and published previously by Almeida-Muradian et al, ${ }^{3,4}$ PLS cross-validations and test set validation were performed. The 14 measurands obtained from this analysis were: moisture, electrical conductivity, free acidity, glucose, fructose, erlose, isomaltose, maltose, melezitose, trehalose, turanose, $\mathrm{pH}$, the sum of glucose plus fructose and the ratios fructose/glucose and glucose/water.

\section{Color analysis}

A Hanna (HI-83221) photometer with direct measurement using cuvettes $(10 \mathrm{~mm})$ was used for the color analysis. Color classes are expressed in millimeters $(\mathrm{mm})$ Pfund grades, compared with an analytical grade Glycerol Standard Reference. ${ }^{2,10}$ The Pfund grade is determined by how many millimeters that spot deviates from the far left of the chart: $0-8 \mathrm{~mm}$ is known as "water white," and 8-17 $\mathrm{mm}$ is "extra white." The darkest, at more than $114 \mathrm{~mm}$ to the right, is dark amber. ${ }^{17}$

\section{HMF analysis}

Honey samples were clarified with $0.2 \%$ sodium bisulphite to avoid interference. HMF content was measured by spectrophotometry at $284 \mathrm{~nm}$, subtracting the back absorbance at $336 \mathrm{~nm}$ according to AOAC International (AOAC)..$^{18}$

\section{Sensorial analysis}

Sensorial analysis was performed by a panel of trained persons at the Bee Research Center, Switzerland, based on the procedures described by Piana et al. ${ }^{12}$

\section{Pollen analysis}

Palynological analysis of the honey samples followed the European technique excluding acetolysis, to maintain the original structural elements. Ten grams of well-mixed honey were dissolved in $20 \mathrm{ml}$ of distilled water, and the sediment obtained after centrifugation was kept in glycerin jelly on glass slides sealed with paraffin. Counting and pollen identification followed Barth, ${ }^{13}$ and interpretation used the methodology of Maurizio and Vorwohl. ${ }^{19}$

\section{RESULTS AND DISCUSSION}

The results of the pollen analysis on the nine honey samples obtained in the Ceará state are presented in Table 1, and show a large spectrum of nectariferous plant species. The blooming indications obtained from the beekeepers do not always agree with the diagnosis using pollen analysis. The honey producers indicated samples 1, 2, and 4 as "Polyflora," meaning heterofloral honey, but this was not confirmed by the palynological analysis, which showed sample 1 as a bifloral honey, sample 2 as an extrafloral honey (lacking any pollen grains), and sample 4 as a monofloral honey of the Lamiaceae family. The third sample analyzed did not agree with the common name (moleque-duro) and the scientific name (Cordia leucocephala) obtained; its pollen grains belong to two very common nectarifeous plants, Piptadenia moniliformis (angico) and a species of the Mytaceae family (murta). Sample 5 was said to be a monofloral honey of Borreria verticillata, but pollen analysis indicated a bifloral honey of this species and also a Lamiaceae species. Samples 6,7 , and 9 agree with the beekeepers' monofloral indication. Sample 8, although monofloral, came from another plant taxon of the same family (Paullinia), as was indicated (Serjania).

Honey from Ceará state were previously analyzed by Barth, ${ }^{13}$ who examined their pollen spectra. The characteristic pollen polyads of Piptadenia moniliformis were also detected in honey samples from the nearby state of Piaui. On the other hand, honey from Ceará frequently show a high percentage of pollen grains of Borreria verticillata. 
Table 1. Palynological data of honey samples from Ceará, Brazil

\begin{tabular}{|c|c|c|c|}
\hline Sample & Origin & Indication of blooming & Diagnosis by pollen analysis \\
\hline 1 & CEARÁ & "Polyflora" & $\begin{array}{l}\text { Bifloral honey of "espinheiro" (pollen type Leg. Mim.*: Mimosa verrucosa) and "vassourinha" } \\
\text { (pollen types Rubiaceae: Borreria densiflora and B. verticillata) }\end{array}$ \\
\hline 2 & CEARÁ & "Polyflora of the Hinderlands" & Extrafloral honey. \\
\hline 3 & CEARÁ & "moleque-duro" & $\begin{array}{l}\text { Bifloral honey of "angico" (pollen type Leg. Mim.: Piptadenia moniliformis) and "murta, rubim" } \\
\text { (pollen type Myrtaceae: Myrcia) }\end{array}$ \\
\hline 4 & CEARÁ & $\begin{array}{l}\text { "Polyflora of the pré Amazon } \\
\text { rainforest" }\end{array}$ & Monofloral honey of "bamburral" (pollen type Lamiaceae: Hyptis) \\
\hline 5 & CEARÁ & "vassourinha" & $\begin{array}{l}\text { Bifloral honey of "vassourinha" (pollen type Rubiaceae: Borreria verticillata) and "bamburral" } \\
\text { (pollen type Lamiaceae: Hyptis) }\end{array}$ \\
\hline 6 & CEARÁ & “angico" & Monofloral honey of "angico" pollen type : Anadenanthera colubrina (Mimosaceae); \\
\hline 7 & CEARÁ & "marmeleiro" & Monofloral honey of "marmeleiro" pollen type :Croton urundeuva (Euphorbiaceae); \\
\hline 8 & CEARÁ & “cipó-uva” & Monofloral honey of “cipó-uva” pollen type: Paullinia carpopodea (Sapindaceae) \\
\hline 9 & CEARÁ & "mangue" & Monofloral honey of "mangue-preto" (pollen type Acanthaceae: Avicennia) \\
\hline
\end{tabular}

*Leg. Mim. = Leguminosae-Mimosoideae, Mimosaceae.

Table 2. Physicochemical analysis results of the honeys using FT-IR ATR

\begin{tabular}{|c|c|c|c|c|c|c|c|c|c|c|c|c|c|c|}
\hline $\begin{array}{l}\text { Samples } \\
\text { (Indication of } \\
\text { blooming) }\end{array}$ & $\begin{array}{c}\text { Moisture } \\
(\%)\end{array}$ & 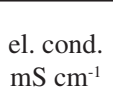 & $\begin{array}{c}\text { acid. } \\
(\mathrm{mEq} / \mathrm{Kg})\end{array}$ & $\begin{array}{c}\text { Glucose } \\
(\%)\end{array}$ & $\begin{array}{c}\text { Fructose } \\
(\%)\end{array}$ & $\mathrm{F} / \mathrm{G}$ & $\mathrm{F}+\mathrm{G}(\%)$ & G/W & $\begin{array}{c}\text { Erlose } \\
(\%)\end{array}$ & $\begin{array}{l}\text { Isomal- } \\
\text { tose }(\%)\end{array}$ & $\begin{array}{c}\text { Maltose } \\
(\%)\end{array}$ & $\begin{array}{c}\text { Trehalose } \\
(\%)\end{array}$ & $\begin{array}{c}\text { Turanose } \\
(\%)\end{array}$ & $\mathrm{pH}$ \\
\hline Sample 1 & 18.17 & 0.43 & 29.60 & 32.07 & 37.54 & 1.19 & 71.10 & 1.20 & 0.00 & 0.17 & 0.15 & 0.33 & 0.66 & 3.80 \\
\hline Sample 2 & 17.58 & 0.32 & 20.36 & 31.72 & 37.70 & 1.21 & 69.35 & 1.21 & 0.08 & 0.26 & 0.36 & 0.61 & 0.83 & 3.89 \\
\hline Sample 3 & 18.62 & 0.67 & 28.77 & 31.21 & 37.23 & 1.23 & 69.74 & 1.23 & 0.00 & 0.29 & 0.86 & 0.36 & 1.09 & 4.15 \\
\hline Sample 4 & 17.60 & 0.25 & 21.52 & 29.51 & 38.01 & 1.28 & 66.73 & 1.32 & 1.10 & 0.29 & 0.53 & 0.34 & 1.00 & 3.55 \\
\hline Sample 5 & 17.54 & 0.48 & 28.80 & 30.75 & 40.27 & 1.29 & 72.38 & 1.30 & 0 & 0.38 & 0.67 & 0.34 & 1.00 & 3.91 \\
\hline Sample 6 & 17.18 & 0.26 & 8.34 & 33.08 & 37.13 & 1.16 & 69.74 & 1.17 & 0.67 & 0.20 & 1.30 & 0.09 & 1.23 & 4.20 \\
\hline Sample 7 & 19.15 & 0.33 & 13.84 & 33.15 & 37.34 & 1.18 & 71.04 & 1.18 & 0.00 & 0.05 & 0.52 & 0.21 & 0.70 & 4.13 \\
\hline Sample 8 & 15.09 & 0.33 & 17.71 & 30.22 & 34.95 & 1.26 & 62.18 & 1.26 & 0.85 & 0.17 & 1.06 & 0.00 & 0.81 & 4.02 \\
\hline Sample 9 & 19.29 & 0.25 & 24.73 & 28.61 & 42.22 & 1.57 & 72.57 & 1.58 & 0.00 & 0.00 & 0.00 & 0.00 & 0.19 & 3.62 \\
\hline
\end{tabular}

*mean of 2 determinations.

The physicochemical results of the FT-IR analysis are given in Table 2, and the color and HMF analyses are presented in Table 3.

From Table 2, we can see that the moisture content of the nine samples varied from $17.18 \%$ to $19.29 \%$, in accordance with the $20 \%$ limit established by Brazilian regulations. ${ }^{11}$ Electrical conductivity varied between 0.25 and 0.67 . $\mathrm{pH}$ ranged from 3.55 to 4.20 , and the acidity of the samples was between 8.34 and $29.60 \mathrm{mEq} / \mathrm{kg}$. The Brazilian regulations ${ }^{11}$ establish a free acidity limit of $50 \mathrm{mEq} / \mathrm{kg}$ for honey, in general. The fructose/glucose ratio was 62.18-72.57, the sum of fructose plus glucose was 1.17-1.58, and the glucose/ water ratio was $0-1.10$.

As expected, these honey samples contained more fructose $(34.95 \%-42.22 \%)$ than glucose $(28.61 \%-33.15 \%)$, and small amounts of other sugars such as erlose $(0.0 \%-1.1 \%)$, isomaltose $(0.0 \%-0.38 \%)$, maltose $(0.0 \%-1.3 \%)$, trehalose $(0.0 \%-0.61 \%)$, and turanose $(0.19 \%-1.23 \%)$. The Brazilian regulation ${ }^{11}$ only establish a minimum of $65 \%$ of reducing sugars for floral honey using the Fehling method, which is less specific than HPLC and FT-IR, which were able to separate each different sugar.

The clearest sample (Sample 8), which is a monofloral honey of "cipó-uva" [Paullinia carpopodea (Sapindaceae)], had the second lowest HMF content $(17.20 \mathrm{mg} / \mathrm{kg}$ ). The highest HMF content (sample $1=289.10 \mathrm{mg} / \mathrm{kg}$ ) is one of the darkest samples (147 Pfund).

There were no special values to distinguish monofloral honey
Table 3. Color and HMF results of the honeys using reference methods

\begin{tabular}{ccc}
\hline $\begin{array}{c}\text { Samples } \\
\text { (Indication of blooming) }\end{array}$ & $\begin{array}{c}\text { Color } \\
\text { (Pfund) }\end{array}$ & $\begin{array}{c}\mathrm{HMF} \\
(\mathrm{mg} / \mathrm{Kg})\end{array}$ \\
\hline Sample 1 & 147 (Dark Amber) & $289.10 \pm 0.57$ \\
Sample 2 & 101 (Amber) & $72.57 \pm 23.71$ \\
Sample 3 & 150 (Dark Amber) & $167.59 \pm 7.03$ \\
Sample 4 & 45 (Extra Light Amber) & $38.42 \pm 2.96$ \\
Sample 5 & 89 (Amber) & $51.35 \pm 1.31$ \\
Sample 6 & 25 (White) & $42.76 \pm 0.61$ \\
Sample 7 & 38 (Extra Light Amber) & $11.26 \pm 0.46$ \\
Sample 8 & 21 (White) & $17.20 \pm 0.15$ \\
Sample 9 & 68 (Light Amber) & $214.98 \pm 33.97$ \\
\hline
\end{tabular}

*mean of 3 determinations.

(Samples 4, 6, 7, and 8) from the others; therefore, further analysis should be performed to characterize this type of Brazilian honey.

The results of the sensorial analysis are shown in Table 4; however, samples 1,2 , and 4 were not suitable for sensorial analysis. This is the first time that these types of honey have been analyzed; therefore, there is no standard for comparison. Further analyses 
Table 4. Sensorial analysis of the samples

\begin{tabular}{|c|c|c|c|c|}
\hline Samples & Color and appearance & Odour & Taste & Texture \\
\hline Sample 3 & $\begin{array}{l}\text { transparent, yellow-brown, } \\
\text { opac, red brown, fark amber }\end{array}$ & $\begin{array}{l}\text { caramel, wax, aromatic, fruit, } \\
\text { roasted, resin, aromatic wood, } \\
\text { vegetal, animal }\end{array}$ & $\begin{array}{l}\text { sauer, frutty, malt, prume, } \\
\text { sweet, fresh, bitter, aromatic, } \\
\text { caramel }\end{array}$ & liquid, cooling, long persistent \\
\hline Sample 5 & $\begin{array}{l}\text { bright amber, clear amber, } \\
\text { translucent, liquid }\end{array}$ & $\begin{array}{c}\text { animal, resine, wax, fruit, malt, } \\
\text { blackcurrent, coffe, caramel, } \\
\text { wood, smoky }\end{array}$ & $\begin{array}{l}\text { sweet, sauer, fruit, animal, rub- } \\
\text { ber, malt, blackcurrant, bitter, } \\
\text { roasted, rose hip, cooked fruit, } \\
\text { chemical, violet, orange }\end{array}$ & $\begin{array}{l}\text { long persistent, liquid, adstrin- } \\
\text { gent, few cristals }\end{array}$ \\
\hline Sample 6 & $\begin{array}{l}\text { yellow, opac, liquid with } \\
\text { cristals }\end{array}$ & $\begin{array}{l}\text { orange, elder flower, aromatic, } \\
\text { tropical fruit, Anis, violet, } \\
\text { resine, wood }\end{array}$ & $\begin{array}{l}\text { sauer, lemmon, frutty, vanilla, } \\
\text { aromatic, Anis, tropical fruit, } \\
\text { sweet, flower, resine, mint }\end{array}$ & $\begin{array}{l}\text { hard cristals, granular, long } \\
\text { persistent }\end{array}$ \\
\hline Sample 7 & $\begin{array}{l}\text { golden, little bubles, liquid with } \\
\text { cristals, dark to bright yellow, } \\
\text { two phases, one opac and other } \\
\text { orange }\end{array}$ & $\begin{array}{l}\text { sweet, aromatic, flower, vegetal, } \\
\text { fruit, rosted, resine, wax, Black- } \\
\text { current, Jasmin }\end{array}$ & $\begin{array}{l}\text { fruit, Apple, sauer, caramel, } \\
\text { sweet, fresh, almond, orange, } \\
\text { bitter orange blossom }\end{array}$ & $\begin{array}{l}\text { powder, cristalline, smooth, soft } \\
\text { cristals, cooling, pasty }\end{array}$ \\
\hline Sample 8 & $\begin{array}{l}\text { transparent, yellow, opac, } \\
\text { homogene }\end{array}$ & $\begin{array}{l}\text { aromatic, flower, wax, roasted, } \\
\text { wood, animal, chemical, fresh }\end{array}$ & $\begin{array}{l}\text { caramel, malt, apple flower, } \\
\text { seet, almond, sauer, resine, } \\
\text { chemical, burned wood, bitter, } \\
\text { warm, cooked fruit, Eucalyptus }\end{array}$ & $\begin{array}{c}\text { cristals, coarse, pasty, long } \\
\text { persistent }\end{array}$ \\
\hline Sample 9 & $\begin{array}{c}\text { golden, translucid, transpar- } \\
\text { ent, little orange, bright amber, } \\
\text { liquid }\end{array}$ & $\begin{array}{c}\text { caramel, wax, cooked fruit, } \\
\text { cooked plume, fruty, wood, } \\
\text { warm }\end{array}$ & $\begin{array}{c}\text { sweet, sauer, bitter, caramel, } \\
\text { cooked fruit, cooked plume, } \\
\text { Vanilla }\end{array}$ & $\begin{array}{l}\text { cooling, smooth, liquid, smoth } \\
\text { cristals, short persistent }\end{array}$ \\
\hline
\end{tabular}

should be performed to produce a sensorial standard for these types of Brazilian honey.

\section{CONCLUSIONS}

Identifications of the source flowers by the beekeepers did not always correspond to the palynological identification. Only four samples had the same identification (producer and microscopic analysis). Common plant names are often misleading; therefore, use of scientific names, in addition, is the best way to identify honey origins.

The clearest honey (sample 8) was also the one with the lowest HMF content and the darkest honey (sample 1) had the highest HMF content.

Honey samples showed values of $17.18 \%-19.29 \%$ for moisture; $0.25-0.67$ for electrical conductivity; $8.34-29.60 \mathrm{mEq} / \mathrm{kg}$ for acidity; $28.61 \%-33.15 \%$ for glucose; $34.95 \%-42.22 \%$ for fructose; $1.16-1.57$ for the fructose/glucose ratio; $62.18-72.57$ for the sum of fructose plus glucose; $1.17-1.58$ for the glucose/water ratio; $0 \%-1.10 \%$ for erlose; $0 \%-1.38 \%$ for isomaltose; $0 \%-1.30 \%$ for maltose; $0 \%-0.34 \%$ for trehalose; $0 \%-1.23 \%$ for turanose; $3.55-4.20$ for $\mathrm{pH} ; 11.26-289.10$ $\mathrm{mg} / \mathrm{kg}$ for HMF.

The sensorial analysis indicates different sensations for each type of honey.

Further analysis is planned to obtain more samples to confirm this preliminary work.

\section{ACKNOWLEDGMENTS}

The authors acknowledge CAPES, FAPESP and CNPq for scholarships, A.S. Freitas for assistance with palynological techniques, R. Badertscher, A. Liniger, and C. Cast for helping with FT-IR ATR analysis, and CEARAPI-Apicultura e Podutos Orgânicos Ltda. for the honey samples.

\section{REFERENCES}

1. Da-Wen, S.; Infrared Spectroscopy for Food Quality Analysis and Control, $1^{\text {st }}$ ed., Elsevier: Dublin, 2008.
2. Bogdanov, S.; Ruoff, K.; Persano Oddo, L.; Apidologie 2004, 35, S4.

3. http://www.agroscope.admin.ch/publikationen/einzelpublikation/index html?aid=28839\&lang=de\&pid=28848, accessed in November 2013.

4. Almeida-Muradian, L. B.; Stramm, Klaus, M.; Estevinho, L. M.; Int. J. Food Sci. Technol. (2013), doi:10.1111/ijfs.12297.

5. Lichtenberg-Kraag, B.; Apidologie 2003, 34, 479.

6. Ruoff, K.; Iglesias, M. T. R.; Luginbühl, W.; Bosset, J.; Bogdanov, S.; Amado, R.; Eur. Food Res. Technol. 2006, 223, 22.

7. Ruoff, K.; Luginbühl, W.; Bogdanov, S.; Bosset, J. O.; Estermann, B.; Ziolko, T.; Kheradmandan, S.; Amadò, R.; Eur. Food Res. Technol. 2007, 225,415 .

8. Ruoff, K.; Luginbühl, W.; Bogdanov, S.; Bosset, J. O.; Estermann, B.; Ziolko, T.; Amado, R.; J. Agric. Food Chem. 2006, 54, 6858.

9. Bogdanov, S.; Bieri, K.; Kilchenman, V.; Gallmann, P.; ALP Forum $\mathbf{2 0 0 5}, 23,3$.

10. Fell, R. D.; Am. Bee J. 1978, 18, 782

11. http://sistemasweb.agricultura.gov.br/sislegis/action/detalhaAto.do?me thod=consultarLegislacaoFederal, accessed in November 2013.

12. Piana, M. L.; Persano Oddo, L.; Bentabol, A.; Bruneau, E.; Bogdanov, S.; Apidologie 2004, 35, S26.

13. Barth O. M.; O Pólen no Mel Brasileiro, Editora Luxor: Rio de Janeiro, 1989.

14. Barth, O. M.; Scientia Agrícola 2004, 61, 342.

15. Barth, O. M.; Bastos, D. H. M.; Maiorino, C.; Benatti, A. P. T.; Ciênc. Tecnol. Aliment. 2005, 25, 229.

16. Ferreira, E. L.; Lencioni, C.; Benassi, M. T.; Barth, O. M.; Bastos, D. H. M.; Food Sci. Technol. Int. 2009, 15, 251.

17. Brasil. Ministerio da Agricultura. Secretaria Nacional de defesa Agropecuaria. LANARA: Metodos analisticos oficiais para controle de produtos de origem animal e seus ingredientes. Laboratorio Nacional de Referencia Animal: Brasilia, 1981.

18. AOAC; Official Methods of Analysis of the Association of Official Analytical Chemists. Association of Official Analytical Chemists: Arlington, 1990.

19. Louveaux, J.; Maurizio, A.; Vorwohl, G.; Bee World 1970, 59, 139. 